\title{
MIGRANT WORKERS: RECRUITMENT AND TRAVELLING FROM INDONESIA TO TAWAU (SABAH) MALAYSIA
}

\author{
${ }^{1}$ Syed Abdul Razak Sayed Mahadi, ${ }^{2}$ Hanafi Hussin, ${ }^{* *} \&{ }^{3}$ Abdullah Khoso ${ }^{* *}$ \\ $\left({ }^{*}\right.$ First author, ${ }^{* *}$ Corresponding Author) \\ ${ }^{1}$ Department of Anthropology and Sociology, ${ }^{2}$ Department of Southeast Asian \\ Studies, ${ }^{3}$ Gender Studies Programme \\ Faculty of Arts and Social Sciences \\ ${ }^{2}$ Institute of Ocean and Earth Sciences (IOES) \\ University of Malaya \\ (hanafih@um.edu.my, syedabdrazak@um.edu.my, \\ abdullahkhoso@hotmail.com) \\ DOI: https://doi.org/10.22452/brj.vol12no1.2
}

\begin{abstract}
Migrant workers' recruitment and travelling from Indonesia to Tawau (Sabah), Malaysia is a serious matter, which has not been thoroughly assessed especially the role or help of local employers in Sabah and the (un)secrete routes they use to bring the undocumented migrant workers to Sabah. This article is based on the Indonesia Labour Migration to Sabah (ILMS) Survey (in Syed Abdul Razak [2010]) conducted in 2009 and 2010, in which 896 migrant workers (both documented and undocumented) were interviewed. Also, informal interviews were conducted with employers, intermediaries and the officials in Malaysia and Indonesia. The article found that mandors and local brokers/village sponsors played an important role in the recruitment process of migrant workers. Mandors and local brokers (could be the village sponsors) worked within the social networks; they formerly linked employers with prospective migrant workers; while the brokers linked new migrants to institutional networks that operated through legal and unauthorised channels. However, the real demand or space for undocumented migrant workers was created from Sabah. The employers played an important role to sustain the problem of undocumented migrant workers. The study also found various factors, which facilitated migrant workers' movement to Sabah that included improvements in water transport and telecommunication systems, the longestablished, familiar networks, and the availability of groups which provided fake documents. There was more inclination to use informal channels because of the cost and procedures, whereas the migrant workers willing to take any kind and
\end{abstract}


level of risk in search of livelihoods. The article concludes that for migrant workers, there was no clear distinction between legal and undocumented recruitment because the same people (mandors) arranged both things for them, but the real pull or demand came from the local people in Sabah.

Keywords: migrant workers, recruitment, travelling, illegal, Tawau, Indonesia

\section{Introduction}

The term illegal migrant workers, illegal immigrants, undocumented migrant workers or 'irregular migrant workers are usually used by the destination state to define the foreign nationals' status without the documents necessary under the immigration regulations to enter, live or work in the state (IOM, 2010, p. 7). In Malaysia, they are often referred to as "Pendatang Asing Tanpa Izin" (PATI) or illegal immigrants (Kassim, 2005a). Estimating the actual number of foreign workers in Malaysia is difficult due to the presence of legal and illegal migrant workers who often bring their families, a trend that seems to be more apparent in Sabah than in Peninsular Malaysia (Kanapathy, 2006).

A conservative estimation by the Immigration Department of Malaysia (IDOM) was that there were between 500,000 and 1.8 million illegal workers in 2011 in Malaysia; however, employers' associations and trade unions believe the number is higher (Kassim \& Mat Zin, 2011). Malaysia has a large number of illegal migrant workers mainly from Indonesian nationality (Devadason, \& Chan, 2013). In Sabah, most of the illegal migrants come from Indonesia (Hugo, 2000; Kassim, 2005a). In 2009, in Sabah, 312,837 illegal migrants were registered with their dependents without documents (Mulia, 2011).

There are found many causes of an increasing number of illegal migrant workers, especially from Indonesia. Some researchers suggested that the problem existed because of the lack of knowledge among Indonesian migrant workers about the proper migration procedures, which make them more vulnerable to exploitation by intermediaries who operate illegal movement (IOM, 2010; Djelantik, 2011). Other researchers have pointed out at the higher cost of documented migration systems and also weaknesses in the immigration laws and procedures in Indonesia (Quinn, 2002; Morgan \& Nolan, 2012), as well as in Malaysian laws and procedures (Wan Hassan \& Dollah, 2011). In research on migration from Indonesia to Malaysia, the common factors which cause undocumented migration of workers include geographical proximity, similarities 
in language and culture, historical links, and well-established migration networks (Hugo, 2000; Wong \& Teuku Anwar, 2003; IOM, 2010).

Social networks and the migration industry (Spaan, 1994; Wong \& Teuku Anwar, 2003) often facilitate it. Undocumented migration had badly affected education (Peters, 2005), health services and security as well as politics and citizenship (Wan Hassan \& Dollah, 2011). A study on migration from the East Flores, East Nusa Tenggara to Sabah found that of 118 deported migrants, about 60 per cent were dependants, indicating that most dependants were of illegal status (Raharto, Romdiati, Hugo, \& Bandiyono, 1999). Also, illegal calos and tekongs often take advantage of migrants' inability to read and their limited understanding of labour migration regulations. It has possibly spurred labour migration through illegal channels (Raharto, 2007). Many migrants entered Sabah illegally or became illegal after the expiry of their visa passes. They take advantage of these programmes to change their status to legal workers (Kassim \& Mat Zin, 2011). Four regulation programmes were conducted in Sabah between 1988 and 2009. Through these, the government attempted to regularised migrant workers and absorbed them into the formal sectors - besides, the availability of the fake documentation through syndicates in Sabah, the entry and stay of undocumented workers possible (Sadiq, 2005).

Despite many measures under various immigration policies, family migration among legal and illegal migrants is common in Malaysia, particularly in Sabah (Kanapathy, 2006; Kassim \& Mat Zin, 2011). The Federal Special Task Force (FSTF) had recorded 294,704 registered Indonesian migrant workers in 1997; of which 42 per cent were dependants (Kassim, 2005b). In 2009, a special amnesty was granted to undocumented migrant workers and their families; through it, the foreign levy was reduced to half; this encouraged the registration and helped to protect the interests of the employers in the plantation sector in Sabah. Some 312,837 undocumented migrant workers and their dependents were identified in this operation called "Operasi Besepadu" (Kassim, 2005b; Kanapathy, 2006).

Various programmes and initiatives were taken to deport or neutralise Indonesian (and all other) migrant workers (Kassim, 2005b; Kanapathy, 2008). However, the number of undocumented migrant workers has not decreased. It is because studies have not appropriately assessed the demand side (people in the destination country) services, facilities, supports, procedures, strategies and networks in Sabah, which play the role of magnate (pull factors). Therefore, this article aims to investigate (not all aspects but) how Indonesian migrant workers are illegally recruited with the help of people and networks in Sabah and how they come to Sabah. This article also aims to reassess some of the aspects and want to see if any important change has taken place. 


\section{Methodology}

During 2009 and 2010, the Indonesian Labour Migration to Sabah (ILMS) Survey (cited in Syed Abdul Razak [2010]) was conducted in Sabah (Malaysian) and Indonesia. Total 896 migrant workers were interviewed for the survey, and 20 informal interviews were conducted with different officials and authorities. In addition, the in-depth interviews of six legal and undocumented Indonesian workers were conducted in public places, such as markets, masjids, shops, and residential areas. Informal interviews were conducted with six recruiting agents (known as calo), on Nunukan Island, in Indonesia. Through the snowball sampling method, the key informants helped the researcher to induct the respondents. The key informants accompanied and assisted the researcher on Nunukan Island. The researcher gained some insights into how legal and undocumented middle agents operated, their social networks, semi-legal channels of entry using aspal (authentic but falsified) documents, and the importance of Nunukan as a transit city. The interview with an Indonesian government official provided information on the efficient water transport system that involved cruise ships, ferries and motor boats. During the fieldwork, the researcher visited busy formal and informal ports of entry and witnessed daily trips of both legal and undocumented Indonesian workers to and from Nunukan Island and Pulau Sebatik via ferries and boats. One of the constraints was, many illegal migrants refused to give interviews because they did not like to be identified for fear of being arrested, humiliated and deported.

\section{Findings/Results}

The ILMS Survey shows that out of 896 migrant workers, 670 were married; of which 39.6 per cent were females and 60.4 per cent were males. Further analysis shows that the vast majority of married migrants (91.3 per cent) stayed with their spouses in Sabah, which means only 8.7 per cent had left their spouses behind in Indonesia. Of the total respondents living with their spouses, there was a higher proportion (96.2 per cent) of women migrant workers living with their spouses at the destination in comparison to their male counterparts (88.1 per cent) (Syed Abdul Razak, 2010). Since most of the respondents were documented, this finding indicates that the majority of documented migrant workers preferred staying with their spouses in Sabah. However, their spouses' status could not be ascertained in this research. According to the Malaysian immigration law, a migrant worker's spouse is legal if he or she had a work permit and stayed in Sabah within the 
period stipulated by the contract; however, their children's status remained undocumented.

\section{Illegal means no benefits or services}

These migrants were found working in the informal sector as small traders in the local market, by roadsides, sales assistants in local shops and restaurants, cobblers, barbers and so on. Some of the respondents shared that illegal migrants' life is trapped from all sides. They could not go to medical doctors because they had no documents and they had to rely on the self-medication in case of illness. Due to lack of proper and timely medical attention, many migrants suffer for a long time, and sometimes they go back through illegal channels. They also informed that they did not go to any doctor because they had no documents.

Similarly, a study on foreign workers' employment in Sabah showed that a high percentage (86.4 per cent) of workers illegally employed mainly in the informal sector (Jemon, 2003). The ILMS Survey found that some (2 per cent) migrant workers arrived in Sabah through formal legal recruitment channels became illegal when their employers refused to send them for the medical examination within a month of their arrival because their employers feared that their workers would be sent back home if they were found unfit. It also showed and also confirmed by some workers that the medical certificates collected in Indonesia were not genuine (Syed Abdul Razak, 2010).

The ILMS Survey indicated that the majority of migrant workers had legal status; however, being legal workers did not mean that they had entered Sabah through legal channels (Syed Abdul Razak, 2010). Some of them informed that they had entered Sabah by using tourist visas or border passes, and then they overstayed and worked illegally before taking advantage of the regulation programmes conducted by the Immigration Department of Sabah (IDOS). However, their children were not legal. The majority of the respondents informed that children born to migrant workers in Sabah were considered a burden on health and education services, but in reality, due to their illegal status, migrant children had no access to basic education and subsidised hospital services. Many respondents were surprised to share that when children do not use any health and education services, then how come they were considered a burden. Many of those born in Sabah were stateless because they did not possess documents (especially birth certificates). During the fieldwork, it was reported that there were estimated 50,000 migrant children in Sabah and the number was increasing. 


\section{Illegal recruitment and movement}

Respondents were not asked about their status (legal or illegal) when they had the first time arrived in Malaysia. It was done to avoid making the respondents feel insecure. However, their status was easily understood when they were asked questions related to the medical examination. In the legal recruitment procedure, a medical examination is indispensable. The migrant workers were required to have a medical examination in their country and within thirty days of their arrival in Malaysia; another medical examination must be conducted in clinics approved by the government in Sabah. The medical examination is mandatory.

The ILMS Survey revealed that only 39.5 per cent of the respondents had medical examinations after they had arrived in Sabah (Syed Abdul Razak, 2010). It indicates that the first time they had arrived through either illegal or semi-legal recruitment practice with them later taking advantage of the registration and regulation programmes conducted by the Immigration Department of Malaysia and the Sabah Labour Force Department and then became legal workers. Twentytwo per cent of the respondents did not have any medical examination before or after their arrival in Sabah. It indicates that they had illegally entered Sabah and had not gone through medical examination.

A vast majority (about 90 per cent) of the respondents indicated that social networks consisted of multiple layers of intermediaries, returnee migrants and families and friends in Sabah, who assisted the migrant migrants in the migration process. These all relations, contacts and networks facilitated and supported the illegal migration to Sabah. The respondents informed that the particular networks influence migrants' decision to travel through legal, semi-legal or illegal channels because they support them. Those illegal migrants not coming through any networks were usually not aware of the types of journeys or the documents that they were needed to carry. The ILMS Survey also found that in Indonesia people had little knowledge of the legal and illegal recruitment and channels to come to Sabah (Syed Abdul Razak, 2010). Some of them were able to suggest that it was because they were not educated and aware of the difference between both, and no one informed them about such a difference. It was also informed that the same people (calo) sometimes do both types of legal and illegal recruitment and a common Indonesian were unable to know about the procedure through which they were going to travel and enter into Sabah.

The in-depth interviews, the survey and observations indicated that Indonesian labour migration to Sabah was conducted through three major recruitment processes. The first process of recruitment was very systematic and legal, which often took a long time and at the same time was considered expensive because it took place through various government agencies. It required heavy fees 
in the country of origin and Malaysia. The second recruitment process was done through very trusted senior Indonesian workers (mandors) who played an important role in finding and referring the potential workers (mainly from their family members, relatives and villagers) to employers. However, this process of migration was done through either legal, semi-legal or illegal. In the third recruitment process, there was an important role of the middlemen known as calo or taikonglaut, taikong darat and taikong kerja. These facilitated the recruitment and movement of workers through illegal channels. In this process, there was a reported minimum travel cost, much cheaper, and easier than the other two mentioned above. It entailed serious risks because workers had to cross Malaysian borders from dangerous and secret routes under the darkness of the night.

The Sabah Ordinance (revised 2004) states that recruitment of legal migrant workers must be made through both formal agents in Sabah and Indonesia beginning from 2004 (where jobs, employers and sector are predetermined in a 'calling visa' before border crossing) (Kassim \& Mat Zin, 2011). However, the ILMS Survey indicates that many migrants had entered Sabah through 'semi-legal' and 'illegal' channels, and had not followed legal procedures (Syed Abdul Razak, 2010). The illegal channels were used because of the prevailing social networks, which assisted migrants' travel to Sabah quickly, and with low cost.

The respondents informed that calos/taikongs initiated the illegal recruitment or illegal migration to Sabah. Most of the respondents in the Survey also confirmed that the geographical factors were major reasons for illegal migration of Indonesian workers to Sabah; in specific these geographic factors include proximity, the shared border between Tawau (Sabah) and Indonesia, an extensive coastline that stretches over 1400 kilometres and small islands surrounding Sabah (Syed Abdul Razak, 2010). These small islands played an important role to stay away from the authorities in Sabah. These also enabled calos/taikongs to make secret routes.

The ILMS Survey also indicated that some 21 per cent of respondents had paid more than 1,500,000 Indonesian ringgits to calos. The majority of migrants' travel costs ranged between 2 to 3.5 million Indonesian rupiah (in US dollars from 220 to 385) (Syed Abdul Razak, 2010). It was informed that that travel cost often depended on the type of transport used, the distance from departure to the entry point and mode of entry (illegal, semi-legal or legal). Normally, a travel cost used for illegal channels was much cheaper than those of semi-legal and legal channels. It was because in illegal travelling short distances were used.

All respondents in the ILMS Survey informed that they were employed under a 'contract of service' (Syed Abdul Razak, 2010). However, it is necessary to 
indicate the fact that out-sourcing companies or self-employed contractors, also known as 'contractors for labour services', often recruited illegal migrants in the plantation sector as casual workers verbally bonded under 'contract for service'. They supply workers to plantations based on seasonal needs especially during good harvests and when facing labour shortages. The in-depth interviews in the ILMS Survey found that this service was preferred by employers in small and medium enterprises (SMEs) and in general all sectors, especially plantation, construction and services (Syed Abdul Razak, 2010).

During the survey, it was informed that the migrant workers, including illegal workers, did not enjoy legal rights in the Employment Act and other labour laws. They also could not form or join trade unions as a right to association and were deprived of the bonuses and allowances. They were not supposed to ask or claim for financial incentives because they were illegal even to the fact they were scared to ask for wages on time. However, some of the respondents (as undocumented workers) informed that the only incentive they received on top of their basic wages was the overtime payment. Sometimes they were helpless to accept low wages and no or little financial incentives because they knew that they were undocumented, which provided space to the employers to treat them unfairly (Syed Abdul Razak, 2010).

\section{Border crossing}

Meanwhile, 2.9 per cent of the respondents in the ILMS Survey showed that migrant workers had come to Sabah through speedboats to cross the border, which indicated their undocumented entry (Syed Abdul Razak, 2010). Most of the respondents informed that speedboat services were by people who wanted to enter Sabah without documents. They came from Sungai Nyamuk in Pulau Sebatik (in Indonesia), which shares a border with Malaysia at Tawau region. The undocumented migrants could take advantage of the daily speedboat services that provided services of transfer of goods and passengers between Pulau Sebatik and the Batu Batu jetty near Tawau port. Pulau Sebatik is only 10 kilometres from the jetty. The local people also used speedboats to make a daily trip to purchase groceries and gas cylinders in Tawau town. It was extremely difficult to differentiate between the Indonesian and Malaysian citizens who lived together in Pulau Sebatik. Interestingly it was informed that Indonesians and Malaysians owned the speedboat service. Furthermore, illegal migrants holding aspal border passes could be easily mistaken as locals of Pulau Sebatik or Nunukan.

The ILMS Survey found that Tawau port was an important and main port of entry for Indonesian workers travelling to Sabah (Syed Abdul Razak, 2010). Indepth interviews showed that ferry passengers had to present their travel 
documents that included their passports and social visit passes or border passes at Tawau port. Upon arrival, they received stamps by the immigration. These findings confirm that migrant workers used the semi-legal mode of entry in Sabah. Only a nominal number of migrant workers (3.8 per cent) entered via other entrances; which included Kalabakan, Sungai Udin, Kampong Biawak, and Kampung Ice Box. These places were closely associated gangs which helped people to make unauthorised entry. Those undocumented migrant workers who had entered from Sungai Nyamuk in Pulau Sebatik, they also used speedboats as their main transport to cross the border.

It was informed that some mandors return to their villages, identify and select potential workers mostly from their relatives and friends, and then travel back together to Nunukan Sabah. Mandors sought assistance from the boat owners (calo/taikong laut) to avoid the high costs of obtaining legal travel documents and work permits. They were often their friends and relatives (Figure 1); they helped them to cross the Malaysian border unauthorised from Sungai Nyamuk in Pulau Sebatik.

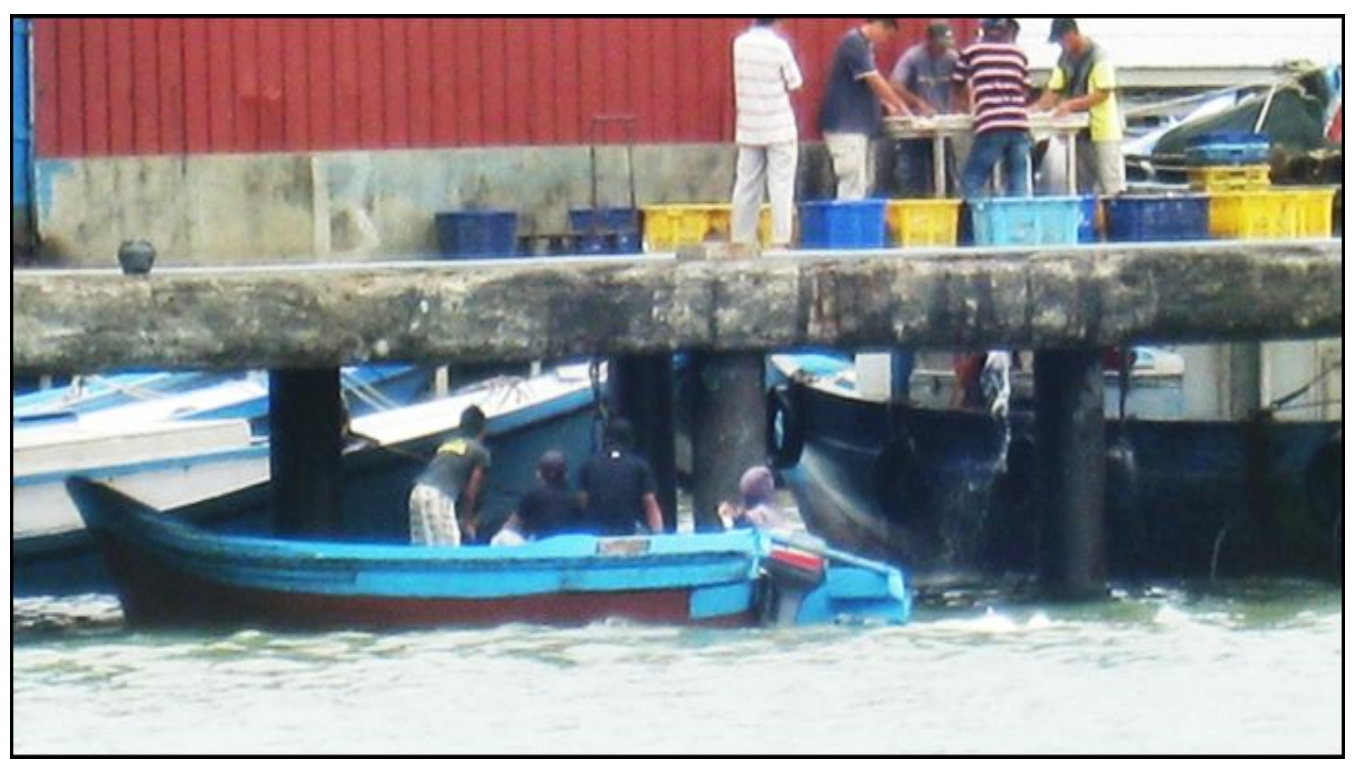

Figure 1: Speedboat from Sungai Nyamuk Arriving Near Tawau Port Transporting Illegal Migrants

(Source: ILMS Survey (in Syed Abdul Razak [2010]).)

The in-depth interviews with a few mandors and Indonesian migrant workers showed that Pulau Sebatik had become a popular route for undocumented 
movement to Malaysia. Speedboats from Sungai Nyamuk (in Indonesian) could easily dock at kampung air (floating villages on the water) located along Tawau shores. Illegal migrants easily accessed floating villages. It was shared that a popular village known Kampung Ice Box was used as a transit point before migrants were transported to their workplaces. Recruitment of illegal workers was often practised by employers (sub-contractors) and smallholders whose plantations were located in the remote areas, which made operations, by local authorities almost impossible.

A detailed interview with an official from the Indonesian Coast and Sea Guard Unit (Kepala Penjagaan Laut Pantai Indonesia) (Figure 2) shows that at least eight illegal routes known as 'lorong tikus' (rat trails) were often used for illegal trafficking of the migrant workers into Sabah. The dangerous routes are taken by illegal taikong laut (sea taikong) using speedboats through mangroves at night-time made it impossible for authorities to detect their movement. Figure 3 shows that there were two trails through Sungai Nyamuk, Pulau Sebatik; three trails through Kalabakan in Tawau; two trails through Sungai Ular, Simengaris in North Kalimantan; and another through Sungai Serudung in Tawau. It was informed that there were 50 more illegal routes in East and West Kalimantan used by taikongdarat (land taikong) to transport migrants in the dark of night. Taikong Kerja (work taikong) received migrant workers and brought them to employers. This established networking system sustained illegal migration to Sabah.

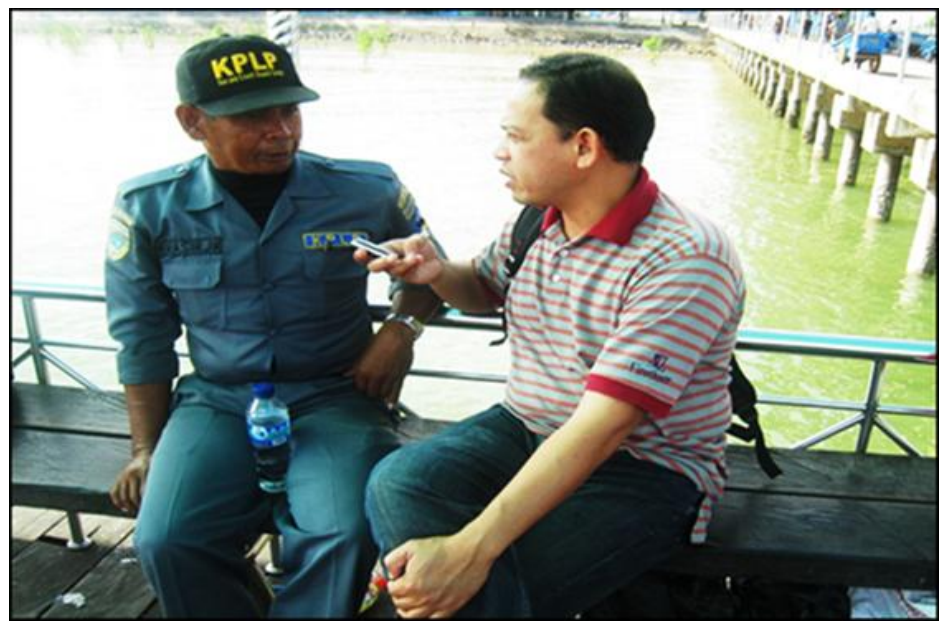

Figure 2: In-depth Interview with an Indonesian Coast and Sea Guard Unit Officer (Kepala Penjagaan Laut Pantai Indonesia) at Nunukan (Source: ILMS Survey (in Syed Abdul Razak [2010]).) 


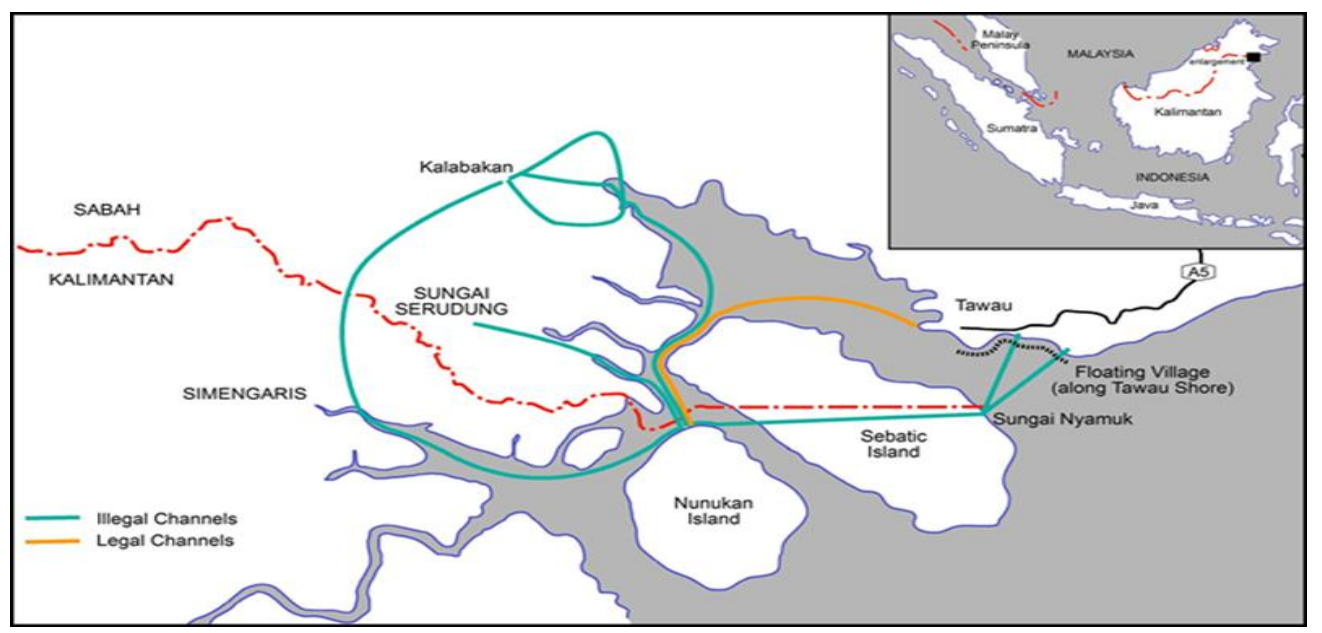

Figure 3: Routes Known for Illegal Border Crossing

(Source: ILMS Survey (in Syed Abdul Razak [2010]).)

Notes: There are two trails through Sungai Nyamuk, Pulau Sebatik; three trails through Kalabakan in Tawau; two trails through Sungai Ular, Simengaris in North Kalimantan; and another through Sungai Serudung in Tawau.

During in-depth interviews with the employers, middlemen and migrant workers, it was found that the issue of illegal workers sustained because the employers wanted them, their demand was in Sabah, therefore, the processes were activated from Sabah to bring workers through illegal and cheap sources so that they should not be financial burden on the employers. The employers were greatly responsible for the issue. The state authorities were aggressive towards employee rather towards the employers. The employers informed that the recruiting of illegal workers was much easier, faster and cheaper; it did not entail lengthy legal processes, and they paid nothing for annual levies, and also did not give financial benefits to illegal employees. It also solved their problem of seasonal or temporary increases in demand for workers especially in oil palm plantations during harvesting seasons. If the illegal workers were arrested or caught by authorities, the employer had not to bear any cost either in emotional, physical or financial terms. They were not blamed for anything. The ILMS Survey confirmed that the illegal recruitment/movement was organised by unlicensed recruiters known as calo, taikong, tauke or mandor who were highly organised and facilitated the entire process of migration from arranging travel documents to securing fake jobs at the destination (Syed Abdul Razak, 2010). This network of recruiters was merely meant to make money by fooling poor workers in their home and destination country (Malaysia). 
An in-depth interview with a registered foreign worker agent indicated that potential migrant workers in Nunukan (who were waiting for legal documents to be ready) often fell prey to the calo/taikongs who influenced them to undertake illegal entry. They were promised immediate jobs without being burdened with the payment of levies. Some calos/taikongs offered financial assistance in the form of money advances, which can be repaid by monthly wage deduction. This activity had caused financial loss to small Foreign Workers Agencies operating in transit cities such as Nunukan and had encouraged illegal migration. Table 1 summarises the migration routes taken by Indonesian migrants to Sabah.

Table 1: Summary of Migration Routes Taken by Indonesian Migrant Workers to Sabah

\begin{tabular}{|c|c|c|c|}
\hline Route & Travel documents & Movement process & Length/Costs/Risk \\
\hline Legal & $\begin{array}{l}\text { An Indonesian } \\
\text { identity card and } \\
\text { passport, entry visa } \\
\text { issued by IDOM } \\
\text { attaché in Indonesia. } \\
\text { - Passed a medical } \\
\text { examination } \\
\text { - Attended a pre- } \\
\text { departure course }\end{array}$ & $\begin{array}{l}\text { - Recruited through a } \\
\text { formal Foreign Workers } \\
\text { Agency in Indonesia } \\
\text { - Enters through a formal } \\
\text { port of entry in Tawau, } \\
\text { Sabah } \\
\text { - Uses a ferry/passenger } \\
\text { ship service or plane to } \\
\text { travel } \\
\text { - Can ensure a safe } \\
\text { journey and entry to } \\
\text { Sabah as well as } \\
\text { workplace }\end{array}$ & $\begin{array}{l}\text { - A lengthy, costly and } \\
\text { complicated } \\
\text { recruitment process. } \\
\text { - A legal migrant } \\
\text { worker is protected } \\
\text { under the Malaysian } \\
\text { employment laws and } \\
\text { regulations, and he } \\
\text { receives more } \\
\text { employment benefits }\end{array}$ \\
\hline $\begin{array}{l}\text { Semi- } \\
\text { legal }\end{array}$ & $\begin{array}{l}\text { A border pass or a } \\
\text { tourist visa (an aspal } \\
\text { Indonesian Identity } \\
\text { card and border } \\
\text { pass can be } \\
\text { purchased in the } \\
\text { border town, } \\
\text { Nunukan) }\end{array}$ & $\begin{array}{l}\text { Recruited directly by an } \\
\text { employer, through a } \\
\text { mandor or an informal } \\
\text { agent in Indonesia } \\
\text { - Enter through a formal } \\
\text { port of entry in Tawau, } \\
\text { Sabah } \\
\text { - Uses a ferry/passenger } \\
\text { ship service or plane to } \\
\text { travel } \\
\text { - Can ensure a safe } \\
\text { journey and entry to } \\
\text { Sabah }\end{array}$ & $\begin{array}{l}\text { - Costs are incurred } \\
\text { when purchasing aspal } \\
\text { documents and travel } \\
\text { tickets. } \\
\text { - The recruitment is } \\
\text { done in a short period of } \\
\text { time but a rather costly } \\
\text { - Becomes illegal when } \\
\text { overstays and works in } \\
\text { Sabah } \\
\text { - An illegal worker is } \\
\text { not protected by } \\
\text { Malaysian employment }\end{array}$ \\
\hline
\end{tabular}




\begin{tabular}{|c|c|c|c|}
\hline Route & Travel documents & Movement process & Length/Costs/Risk \\
\hline & & & $\begin{array}{l}\text { laws and is denied } \\
\text { employment benefits; is } \\
\text { easily exploited by } \\
\text { employers and calos } \\
\text { - Faces the risk of being } \\
\text { identified and deployed } \\
\text { but easy to reenter from } \\
\text { Nunukan }\end{array}$ \\
\hline Illegal & None & $\begin{array}{l}\text { Recruited directly by an } \\
\text { employer, through a } \\
\text { mandor or illegal } \\
\text { calo/taikong in Indonesia } \\
\text { - Enters through an } \\
\text { informal port of entry in } \\
\text { Tawau, Sabah } \\
\text { - Uses a speedboat to } \\
\text { cross the border through } \\
\text { dangerous rat trails } \\
\text { - Is exposed to the risk of } \\
\text { being exploited by calos } \\
\text { during the journey }\end{array}$ & $\begin{array}{l}\text { - The recruitment } \\
\text { process is short } \\
\text { - Costs are greatly } \\
\text { varied from one illegal } \\
\text { calo to another. They are } \\
\text { higher if the migration } \\
\text { costs are borrowed from } \\
\text { a calo. } \\
\text { - An illegal worker is } \\
\text { not protected by } \\
\text { Malaysian employment } \\
\text { laws and is denied } \\
\text { employment benefits; is } \\
\text { easily exploited by } \\
\text { employers and calos } \\
\text { - Faces risk of being } \\
\text { identified and deployed }\end{array}$ \\
\hline
\end{tabular}

Source: ILMS Survey (in Syed Abdul Razak [2010]).

\section{Conclusion}

This article has explored the dynamics and factors of undocumented Indonesian migration to Tawau, Sabah. It shows that geographical proximity, language, cultural and religious similarity, as well as having relatives at the destination have motivated migrants to choose Sabah as a destination.

In addition to the importance of networks, this paper has highlighted the important role played by mandors and t local brokers/village sponsors in migration process especially the recruitment of migrant workers. Mandors and local brokers (village sponsors) worked within their closely knitted social networks; Mandors linked employers with prospective migrant workers, whereas the local brokers 
linked the new migrant workers to institutional networks that operated both legally and illegally. The trend of using mandors to assist in the recruitment process of the new migrant workers will continue to support and sustain the process of migration to different sectors in Sabah. Many employers preferred their relatives and villagers in their recruitment to maintain the flow of reliable workers through the relationship between mandors and new migrants. The research shows that the forces with Sabah have continued to support undocumented migrants so that they maximise their profit.

The study found that the use of long-established, familiar networks; tremendous improvements in water transport and telecommunication systems; and the presence of fake document groups have greatly facilitated movement to Sabah. The tendency of using a semi-legal mode of entry, which provides familiarity and security has decreased the chances to use formal channels, which are centralised, costly and time-consuming, as well as illegal channels, which involved serious risks. There was found no clear dichotomy between legal and illegal recruitment in Indonesian labour migration to Sabah as both legal and illegal elements are intertwined in the movement and recruitment processes.

\section{Acknowledgement}

An earlier version of this article was presented at the $10^{\text {th }}$ International Conference on Malaysia-Indonesia Relations on 16-18 August 2016 at the Faculty of Arts and Social Sciences, University of Malaya. The authors are grateful to the participants at the conference for their valuable comments.

\section{References}

Devadason, E. S., \& Chan, W. M. (2013). Policies and Laws Regulating Migrant Workers in Malaysia: A Critical Appraisal of Policies. Journal of Contemporary Asia, 44(1), 19-35.

Djelantik, S. (2011). Demographic Pressure, Poverty, Human Trafficking and Migrant Workers: An Indonesian Case. Paper presented at the Third Global International Studies Conference on "World Crisis: Revolution in the International Community", Porto, 17-20 August. Retrieved from http://www.wiscnetwork.org

Hugo, G. (2000). Labour Migration from East Indonesia to East Malaysia. Revue Europeenne Migrations Internationales, 16(1), 97-126. 
IOM. (2010). Labour Migration from Indonesia an Overview of Indonesian Migration in Selected Destinations in Asia and the Middle East. Jakarta: IOM.

Jemon, S. (2003). Pengurusan Buruh Asing di Sabah. In A. Kassim (Ed.), Proceedings of "State Responses to the Presence and Employment of Foreign Workers in Sabah" (pp. 37-66). Kota Kinabalu: University Malaysia Sabah.

Kanapathy, V. (2006). Migrant Workers in Malaysia: An Overview. Paper presented at the workshop on "An East Asian Cooperation Framework for Migrant Labour Towards an East Asian Cooperation Framework for Migrant Labour", Institute of Strategic and International Studies Malaysia, Kuala Lumpur, 6-7 December.

Kanapathy, V. (2008). Managing cross-border labor mobility in Malaysia: Two decades of policy experiments. Pacific Economic Cooperation Council (PECC)'s website. Retrieved from https://www.pecc.org/resources/labor/690-managing-cross-border-labourmobility-in-malaysia-two-decades-of-policy-experiments/file

Kassim, A. (2005a). Illegal Immigrants and the State of Sabah: Conflicting Interest and the Contest of Will. In Kassim, A. (Ed.), Proceedings of "State Responses to the Presence and Employment of Foreign Workers in Sabah" (pp. 1-36). Kota Kinabalu: University Malaysia Sabah.

Kassim, A. (2005b). Orang Pelarian di Sabah: Status dan Konflik. In Proceedings of "State Responses to the Presence and Employment of Foreign Workers in Sabah" (pp. 91-114). Kota Kinabalu: University Malaysia Sabah.

Kassim, A., \& Mat Zin, R. (2011). Policy on Irregular Migrants in Malaysia: An Analysis of its Implementation and Effectiveness. Quezon City: Institute for Development Studies.

Morgan, G., \& Nolan, C. (2012, 1 December). Step Up: Improving Recruitment of Migrant Workers in Indonesia. Findings from a Research Visit to Semarang, Indonesia, 3-7 May. Retrieved from http://www.bsr.org

Mulia, D. S. (2011). Social networks, Gender Differences and Survival Strategies: Evidence from Undocumented Immigrants in Sabah, East Malaysia. Bumantara Journal of Social and Political Development, 1(2), 43-64.

Peters, D. (2005). Cross-Border Migration in the Context of Malaysia-Philippines Relations. In Proceedings of "State response to the Presence and Employment of Foreign Workers in Sabah" (pp. 141-166). Kota Kinabalu: University Malaysia Sabah.

Quinn, P. (2002). Dreams Turn to Nightmares for Indonesian Migrants. Migrant Workers, 4(129), 109-114.

Raharto, A. (2007). Indonesian Labour Migration: Issues and Challenges. International Journal on Multicultural Societies, 9(2), 219-235. 
Raharto, A., Romdiati, H., Hugo, G., \& Bandiyono, S. (1999). Migrasi dan Pembangunan di Kawasan Timur Indonesia: Isu Ketenagakerjaan. Jakarta: Cooperation between Pusat Penelitian Kependudukan dan Ketenagakerjaan - Lembaga Ilmu Pengetahuan Indonesia dan Australian National University and Australian Agency for International Development.

Sadiq, K. (2005). When States Prefers Non-Citizens Over Citizens: Conflict Over Illegal Immigration into Malaysia. International Studies Quarterly, 49(5), 101122.

Spaan, E. (1994). Taikongs and Calos: The Role of Middlemen and Brokers in Javanese International Migration. International Migration Review, 28(1), 93113.

Syed Abdul Razak, S. M. (2010). Indonesia labour migration to Sabah: Trends, impacts and changes. Doctoral dissertation, School of Social Sciences, Adelaide University, Adelaide, Australia.

Wan Hassan, W. S., \& Dollah, R. (2011). Pendatang dan Isu Keselamatan di Sabah. Kota Kinabalu: Universiti Malaysia Sabah.

Wong, D., \& Teuku Anwar, T. A. (2003). Migran Gelap: Irregular Migrants in Malaysia's Shadow Economy. In G. Battistella \& M. M. B. Asis (Eds.), Unauthorised Migration in Southeast Asia (pp. 169-228). Zuaexon City: Scalabrini Migration Center. 